\title{
Investigating the structural relationship of mass media on attitude, social influence, product safety and its impact on purchase behaviour of herbal product in Malaysia
}

\section{Sarina Ismail ${ }^{a}$, Nur Aishah Awi ${ }^{\mathrm{a}}$, Monizaihasra Mohamed ${ }^{\mathrm{a}}$, Yusliza Mohd Yusof ${ }^{\mathrm{a}}$, Jumadil Sapu- $\operatorname{tra}^{\mathbf{a}^{*}}$ and Ramayah Thurasamy ${ }^{\mathrm{b}, \mathrm{c}, \mathrm{d}, \mathrm{e}}$}

${ }^{a}$ Faculty of Business, Economics and Social Development, Universiti Malaysia Terengganu, 21030 Kuala Nerus, Terengganu, Malaysia

${ }^{b}$ School of Management, Universiti Sains Malaysia (USM), Malaysia

${ }^{c}$ Faculty of Economics and Business, Universiti Malaysia Sarawak (UNIMAS), Malaysia

${ }^{d}$ Fakulti Ekonomi dan Pengurusan, Universiti Kebangsaan Malaysia (UKM), Malaysia

${ }^{e}$ Fakulti Pengurusan dan Perniagaan, Universiti Teknologi Mara (UiTM)

\section{H R O N I C L E A B S T R A C T}

Article history:

Received: May 10, 2021

Received in revised format: June

30, 2021

Accepted: August 28, 2021

Available online: August 29, 2021

Keywords:

Mass Media

Attitude

Social Influence

Product Safety

Purchase Behavior

Herbal Product

\begin{abstract}
Mass media is a crucial advertising platform and serves as an awareness platform for herbal product businesses. The rising popularity of herbal product consumption is due to the changing of lifestyle and health problems. With the increasing demand for herbal products globally, studies related to the herbal products purchase behaviour are considered very limited. Hence, the current study is written to investigate the structural relationship of mass media on attitude, social influence, product safety and its impact on purchase behaviour of Herbal products in Malaysia. By applying the AttitudeBehaviour Context Theory, this study used several variables, namely mass media toward attitude, social influence, and product safety and purchasing behaviour of herbal products. This study was designed using a quantitative approach through a survey questionnaire. A total of 467 respondents from seven states in Peninsular Malaysia have participated in this study and collected using the intercept survey. The data were analysed using structural equation modelling with a partial least square approach (SEM-PLS) and assisting SmartPLS 3.3.3. The results showed that mass media has a significant positive effect on attitude, social influence and product safety. Also, attitude, social influence and product safety have a significant positive impact on the purchase behaviour of herbal products. In conclusion, this study identified that mass media influence on attitudes is the strongest predictor, followed by the effects of the mass media on social influence. These findings indicated that the mass media play an essential role in influencing attitude, social influence, and product safety. Followed by attitude, social influence, and product safety that significantly impact the purchase behaviour of herbal products. The finding of this study provides insightful information to the entrepreneurs regarding consumers purchase behaviour.
\end{abstract}

\section{Introduction}

The continuous advertising from mass media serves as an awareness platform for herbal product businesses, as most are opting for natural claimed effects to stay healthy and generating positive responses (Cheah et al., 2019). An increase of herbal awareness and benefits as health care and alternative medicine boosted the global market for herbal products with the recorded revenue of 133,800 billion US\$ in 2018 , and it was forecasted to increase to $\$ 48.18$ billion in Asia and 159,800 billion US\$

* Corresponding author.

E-mail address: jumadil.saputra@umt.edu.my (J. Saputra)

(C) 2021 by the authors; licensee Growing Science, Canada. doi: $10.5267 /$ j.ijdns.2021.8.014 
worldwide in 2025 (QYR Research, 2019; Research and Markets, 2020). In addition, India is projected to be the fastestgrowing market with a CAGR of $10.84 \%$ for 2020-2025 compared to other countries (Research and Markets, 2020). However, this report provided the global market share (sales and revenue) for world trade herbal companies in 2019 before the outbreak of COVID 19; in the recent report, the global herbal products market is revised and is expected to reach USD 166.2 billion by the year 2027. After considering the trade tensions, slow economic growth, and Covid-19 Pandemic crisis (Global Industry Analysts. Inc, 2020; Report Globe, 2020).

Meanwhile, in Malaysia, the development of the herbal industry is commonly due to the traditional practice of its ethnic diversity, which has been introduced over six centuries ago as a conventional medication by older generations to treat several illnesses (Wahab et al., 2019). Besides, Malaysia has diverse biodiversity and is one of the world's oldest rainforests with over 2,000 medicinal plants. Subsequently, Malaysia has a competitive advantage in herbal products due to its vast supply of raw ingredients, which are used to facilitate well-being or disease prevention (Ahmad et al., 2015; Alexieva et al., 2020). In addition, herbal products are preferable to conventional due to the growth of a healthy lifestyle and inexpensiveness that pushes the market size of herbal products to its maximum (El-Dahiyat et al., 2020; S. Ismail \& Mohd Mokhtar, 2017; Mazhar et al., 2016). Besides, Government funding on research and development in herbal medicine is also the primary factor (Haque et al., 2020; Ismail \& Mohd Mokhtar, 2016b; Rojas-Rivas et al., 2018; Wegener, 2017). Furthermore, due to the herbal industry's recognition and high economic potential (Muhamad et al., 2018), the herbal sector was selected as a new source of economic growth under the agribusiness New Key Economic Areas programme (NKEA). Consequently, the Malaysian's Government has initiated the program involving the key herbal industry players, authorities, and researchers to work on this program, and concurrently it can contribute to Malaysian GDP from RM19 billion to RM28 billion by 2027 (MIDA, 2020 ; Tan et al., 2020).

Several studies have shown that people gradually care about their health and want to sustain a healthy lifestyle by using products that can improve their health (Marimuthu, 2019; Shih et al., 2017). As the world is currently battling against the Covid-19 pandemic, and due to the unavailability of vaccines in the initial stages of the crisis, herbal medicine is used to slow down the spreading of the virus (Huang et al., 2020; Lee et al., 2020). In addition, it allows the herbal industry player to venture into the opportunities to diversify its product offering (Farizah et al., 2015). There are varieties of herbal products in Malaysia's market, and it was mainly due to the cultural diversity that existed in the societies. Traditional Chinese Medicine, Jammu and Ayurveda are few examples of conventional medication that uses various herbs and botanical plants as their main ingredients to cure illness or health maintenance. And they are among the preferable choices and alternatives among Asian peoples. Even though there is a tremendous increment of sales and popularity and usage of herbal products across the globe, which have sparked an interest among many others, unfortunately, the effectiveness of herbal products is not thoroughly examined. Prior studies also identified that many herbal products had not been thoroughly studied, and their use is not regulated (Bandaranayake, 2006; Holt \& Chandra, 2002; G Rezai et al., 2013).

Furthermore, the limited understanding of the possible side effects has become more challenging (Ekor, 2014). The issues related to the safety of the herbal product are also alarming due to some reports contradicting the statement that the herbal product is perceived to be safe and readily available to be used (Lynch \& Berry, 2007). In addition, herbal substances have been identified as potentially producing toxicity and significant adverse reactions in people (Reda et al., 2014). Now there are also cases reported connected herbal products associated with adverse side effects and toxic effects from more significant life-threatening side effects including acute liver failure, kidney failure, gastrointestinal problems to less severe side effects like sleeping disorder (Calitz et al., 2015; Corey et al., 2016; Crescioli et al., 2018; Douros et al., 2016; Gok \& Ulu, 2019; Lauche et al., 2018; Lee et al., 2020; Lin et al., 2019; Navarro, 2019; Oketch-Rabah et al., 2020; Real et al., 2019; Shaito et al., 2020).

In Malaysia, the traditional medicines act was enacted in January 1992, which aims to protect customers. According to this act, each Herbal product to be marketed in Malaysia must be registered and undergo the necessary screening process. National Pharmaceutical Regulatory Agency (NPRA) is responsible for processing registration applications for herbal products. From 2016 to 2020, three thousand four hundred fifty new products were registered, and during that period, 33 products were cancelled due to adulterants issues (NPRA, 2020). The routine analytical tests conducted on 1445 samples to assess the quality of herbal products in 2020 found that 184 samples were adulterated. This screening process ensures that the products' quality, safety, and effectiveness are guaranteed before being marketed. However, quality and safety screening of herbal products conducted by NPRA is limited to the screening of counterfeit mixed substances and contaminants such as heavy metals and microorganisms only (Jantan, 2006). As a result, prior research has examined the reaction of the toxicity effect of the utilised herbal product (Abdualmjid \& Sergi, 2013; Ang et al., 2003, 2005; Woolf, 2003). Ironically there is a lack of evidence on safety, efficacy, and concerns related to herbal products from in consumer perspective (Barnes, 2003; Bent, 2008; Brown et al., 2009b; Hussin, 2001; Lutz, 1999; Taufique \& Vaithianathan, 2018; Wilcock et al., 2004).

In addition, a previous study identified that product safety is a significant determinant factor in quality whether the product is safe to buy or use (Chaudhuri \& Holbrook, 2001; Lodorfos et al., 2006; Magkos et al., 2006; N Michaelidou \& Hassan, 2008; Valeckova, 2012). Another study also has identified that product safety can affect customer attitude and purchase intention (Fleșeriu et al., 2020; Hashmi et al., 2012; S. Ismail \& Mokhtar, 2015a; Kaufmann et al., 2012). The study by Golnaz Rezai 
et al. (2014) and Silva and Sandika (2011) have identified that product safety is the essential factor that shapes customer attitude. Prior studies related to Herbal products have a focus on research in various areas such as Herbal consumption (Adam et al., 2017; Bellikci-Koyu et al., 2020; Brown et al., 2009a; Chaloupkova et al., 2020; Dailey et al., 2003; Khan et al., 2011; Nik Yusof Fuad et al., 2020; Nookabkaew et al., 2006; Sabery et al., 2019; Sumngern et al., 2011; Welz et al., 2018; Wilhoite et al., 2014). Customer awareness on Herbal Product (Banu Rekha \& Gokila, 2015), Customer perception on Herbal Product (Karim et al., 2011; Pujari et al., 2015; Thanisorn et al., 2012). Usage Pattern (Karlowicz-Bodalska et al., 2016; Mahomoodally \& Ramalingum, 2015; Ritchie, 2007; Tangkiatkumjai et al., 2013), Purchase Pattern (Archer \& Boyle, 2008; Nair $\&$ Pillai, 2011). Based on the current understanding, there is a lack of studies on how mass media and product safety can influence consumers to purchase herbal products in marketing.

\section{Literature Review}

\subsection{Purchase Behaviour}

Studies that have been conducted related to purchasing behaviour have long attracted the attention of researchers, where knowledge related to behaviour is believed to help researchers about what users think and how they will behave. Besides the understanding of purchase behaviour able to assist the entrepreneur in determining marketing plan, establish the marketing strategies and securing the business's long-term sustainability (Belland et al., 2017; Bukhari et al., 2020; Kim \& Chung, 2011; Rana \& Paul, 2017; Vadakepat, 2013). According to other studies, purchasing behaviour is complicated and varies by group and segment (Dangelico \& Vocalelli, 2017; Shafiq et al., 2011). Furthermore, purchase behaviour plays a critical role in product performance due to its complex purchasing behaviour. Besides, the complexity of purchase decisions is based on motivational factors, culture, community, locality, family, and various other factors (Ismail \& Mohd Mokhtar, 2016a; Sharma $\&$ Trivedi, 2016). Other studies related to purchasing behaviour concentrate on mental, emotional, and physical activity to meet the requirements and wants of customers who choose, acquire, and use the product (Balachandran \& Hamzah, 2017; Jaiswal \& Kant, 2018). Apart from that, consumers' purchasing behaviour is also affected by marketers' activities, which have inadvertently changed the way consumers behave in a particular way, prompting marketers to devise policies that would have the most impact on them (Alzubaidi et al., 2020; Kumar \& Ghodeswar, 2015). A past study also identifies that environment, reference groups, family members, salespeople, cultural, social, personal, and psychological factors impact consumer purchase behaviour (Fandos \& Flavián, 2006; Ramya \& Ali, 2016; Vani et al., 2010). Purchase behaviour, according to Ajzen (1985), is defined as people's preparedness and willingness to buy a specific product or service. Several predictors of purchasing behaviour have been identified in previous studies, among them are intention (Bagherzad et al., 2011; Fanny Putera Perdana et al., 2019; Hung et al., 2019; Lim et al., 2016; Rana \& Paul, 2017; Sreen et al., 2018; Sultan et al., 2020; Zhang et al., 2020), Subjective Norm (Li et al., 2020; Moshi et al., 2020; Tan et al., 2017; Zhang et al., 2020), Perceived Behavioural Control (Arli et al., 2018; Ibrahim et al., 2019; Judge et al., 2019; Ogiemwonyi et al., 2020; Ogiemwonyi \& Harun, 2020; Richards et al., 2016)

\subsection{Mass Media}

With the increasing use of herbal products, various advertisements are now advertising the products' effectiveness locally and internationally. The continuous advertising from mass media serves as an awareness platform for herbal product businesses, as most are opting for natural claimed effects to stay healthy and generating positive responses (Cheah et al., 2019). According to Parle and Bansap (2005), advertising in mass media has increased consumer awareness and respectability and credibility of herbal products. Moreover, Nur Nadirah et al. (2016) argue that food and beverage related advertising can influence behaviour (Abdullah \& Salleh, 2010). In addition, Warner and Forward (2016) also found that mass media can influence attitudes and subjective norms. At the same time, the study of Simpson et al. (2016) stated that if the buyer is exposed to repeated advertisements, then the greater the probability that it can change the consumer perception of the product and indirectly affect the purchase behaviours (Ho et al., 2016). Furthermore, mass media dramatically influences how consumers react to having a healthy diet. Unfortunately, mass media are often misleading in promoting herbal products without providing evidence scientifically. The chemical substances in herbal products can be life-threatening without many people knowing about them (Qian et al., 2019; Yeh et al., 2020). Moreover, the increase in customer awareness of herbal products due to rapid developments in mass media has been a significant challenge for business in global markets (Golnaz Rezai et al., 2013; Vadakepat, 2013). Due to the lack of study on how mass media influences potential customers about health care and healthcare-seeking behaviour (Goh et al., 2019). Thus, this study identifies three hypotheses which are:

$\mathbf{H}_{1}$ : Mass Media has a positive effect on attitude.
$\mathbf{H}_{2}$ : Mass Media has a positive effect on social influence.
$\mathbf{H}_{3}$ : Mass Media has a positive effect on product safety.

\subsection{Attitude}

Attitude is a prevalent topic and is often the focus of social science and health behaviours researchers as it can predict consumer behaviours (Ajzen, 2001; Spears \& Singh, 2004; Vries et al., 1988). In addition, attitude is also an assessment of 
individuals, whether positive or negative, towards an object, individual, institution, or event (Ajzen, 2012b; Ajzen \& Fishbein, 2005; Ajzen \& Madden, 1986). In general, past studies have recognised the importance of attitude in assessing certain good or bad behaviours and influencing actual purchases(Ajzen \& Fishbein, 1980). Consumer attitudes are often influenced by perceptions, motivations, and external variables while making judgements (Fishbein \& Ajzen, 1975). Different cognitive and emotional constructs influence people's attitudes regarding products(Mihaela-Roxana \& Yoon, 2010). Previous research has shown that an individual's evaluation or action, whether good or negative, is influenced by personal characteristics that influence their attitude toward Purchase behaviour (Ajzen, 2012a; Conner et al., 2001).

According to Ramayah et al. (2010), attitudes encompass the individual's practical consequences related to the behaviour. Meanwhile, attitude is a psychological emotion that is transferred through consumer evaluations, and when it is positive, it leads to positive behavioural intentions (Haque et al., 2018). Furthermore, consumer behaviours toward doing specific actions or behaviours are influenced by both internal and external sources of experience and knowledge of the object. In support of the viewpoints mentioned above, a little research has been conducted, with data indicating that attitudes directly impact behaviour rather than intention (Hashjin et al., 2014). Marinac et al. (2005) discovered that attitude influenced the use of herbal products. In a similar vein, Thongruang (2008) found that one's attitude affects their use of herbal medicine. Furthermore, Brown et al. (2009a) observed comparable effects, while Mitha et al. (2013) discovered that attitude influenced purchasing herbal products. The following hypotheses are suggested in this context.

\section{H4: Attitude has a positive effect on purchase behaviour.}

\subsection{Social Influence}

Social influence is a second driver of behavioural intention in the TPB model. In the TPB and TRA models, social influence is used interchangeably with subjective norms (Izuagbe et al., 2019), which means that most people are important and close to an individual subjectively affecting the individual's behaviour toward executing an act. Conclusion indicates that individuals will feel social stress while performing behaviours because they are motivated to adhere to individuals, groups, or beliefs allowed by other individuals (Azjen, 1991; Sun et al., 2019). For example, the influence from family, friends, co-workers, media and social media could lead to a customer's willingness to use and purchase herbal products. Besides, the studies related to social influence have been widely discussed in the past literature and it is generally accepted that social influence is a predictor of an individual's behaviour (Kusumawardhani et al., 2019; Li et al., 2020) which positively impacts the customer's behaviour in this context study decision to buy herbal products. Empirically, the link between social influence and customer's purchase behaviour has been proven in various settings, such as buying organics and green products (Bai et al., 2019; Basha \& Lal, 2019; Mohammed, 2020; Sun et al., 2019). Zahran et al. (2012) also confirmed that social influence does influence herbal buying intention in Malaysia. This study demonstrates the social influence and the bulk of previous studies, indicating that when consumers learn that people close to them tend to buy herbal products, they will change their minds. As a result, the following assumptions are made in this study:

\section{Hs: Social Influence has a positive effect on purchase behaviour.}

\subsection{Product Safety}

The consumption of herbal products as medicine in human life has recently received much attention due to product safety concerns. Product safety generally denotes a consumer's perceptions of the safety of the desired product (Grunert, 2005; Perrea et al., 2015). Product safety does not always refer to the end product's quality but also applies to the entire production process, influencing customers' perceptions of the product's safety (Michaelidou \& Hassan, 2008; Michaelidou \& Hassan, 2014). This perception could then help customers in deciding whether a product is safe to buy and use. Meanwhile, prior research has identified several issues related to the adverse reaction risk regarding the safety of using herbal products (Ekor, 2014; Zhou et al., 2019). On the other hand, consumers still assume that herbal products are safe to take since they are prescribed by certified medical doctors (Boullata \& Nace, 2000). Therefore, it is inferred in this study that when a consumer perceives the herbal product is safe, their intention and the actual purchase will be higher. In other words, product safety is a critical factor in influencing a product's buying behaviour or usage (Basha \& Lal, 2019; S. Ismail \& Mohd Mokhtar, 2016a). The link between product safety and purchase behaviour has been identified in past studies. For example, a study conducted in Lebanon revealed that product safety is one of the main factors influencing their decision to buy organic foods (Tleis et al., 2017). In a similar vein, a study by Shaharudin et al. (2010) discovered that product safety was positively related to customers' herbal medicine usage. Hence, it is hypothesised that.

\section{H6: Product safety has a positive effect on purchase behaviour.}

\subsection{Attitude-Behaviour Context Theory}

Attitude-Behaviour Context Theory is a flexible theory explaining that one's behaviour is an inter-related outcome of internal and external factors. Behaviour (B) in many social science studies is an interactive product of both personal sphere Attitudinal 
variables (A) and contextual factors (C) which by some other scholars postulated that one's behaviour is not only significantly impacted by their internal psychological factors but also the external factors that are acting upon it (Shi et al., 2019; Stern, 2000; Xu et al., 2017). According to this theory, the contextual factors (C) not only directly influence one's behaviour (B) but also indirectly influence the behaviour from its interaction with attitude (A) (Ertz et al., 2016). Other studies stated that the relationship between attitude $(\mathrm{A})$ and behaviour $(\mathrm{B})$ is significantly strengthened with the presence of external condition $(\mathrm{C}$; sometimes known as context); behaviour is only manifested when an individual developed a positive attitude towards it and under the strong influence of contextual factors (Dhir et al., 2021). It was developed by Stern and colleagues to overcome the criticisms of its predecessor, Theory of Reasoned Action (TRA) and Theory of Planned Behaviour (TPB), due to its neglect of external contextual factors (Stern, 2000). This theory has been widely used in environmental-related studies, including proenvironmental behaviour, green purchase behaviour (Goh \& Balaji, 2016), green consumption (Nguyen et al., 2019), which provide empirically testable hypotheses for such related studies. Thus, we believe that the ABC model is a relevant theory to study the herbal product purchase behaviour whereby the influence of mass media and product safety are present and active predictors. In this study, by using a comprehensive Attitude-Behaviour Context model theory, the interaction of attitudinal and external conditions was specified and examined; attitudinal factors (attitude and social norms) and external contextual factors (e.g., mass media and product safety) towards individual's purchasing behaviour in herbal-related products (Fig. 1).

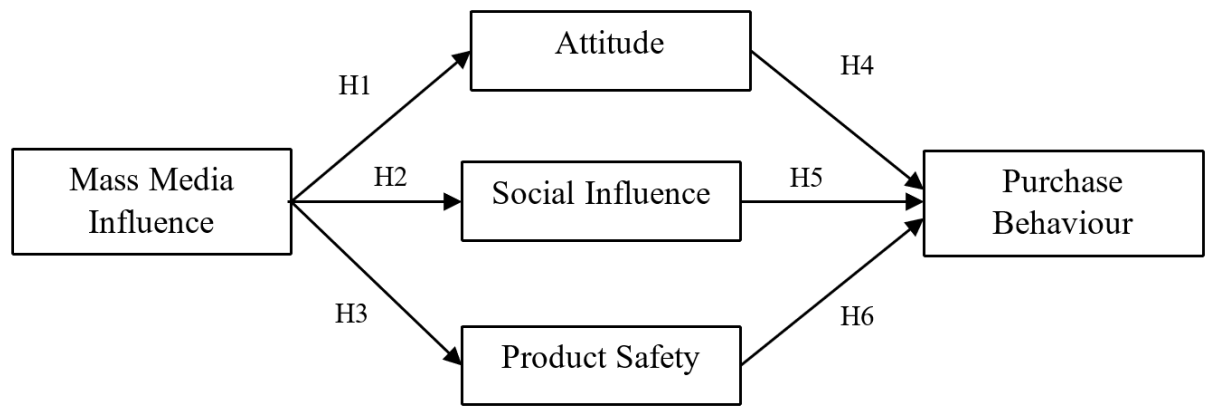

Fig. 1. Research Framework

\section{Materials and Methods}

This study used a non-probability purposive sampling method due to the unavailability of a sampling frame. There are two criteria set for this study. First, they need to be 18 years old, considering young adults are mature enough to purchase herbal products, and have different purchasing behaviours than older generations. The second criterion is that they must have experience using any herbal product before. Data was collected in seven states in Peninsular Malaysia e.g., Kedah, Melaka, Negeri Sembilan, Perak, Perlis, and Selangor using intercept surveys. And to determine the sample size, this study followed the suggestion from Hair et al. (2014) and Kline (1998) that the sample size should be at least ten times the item. Therefore, the minimum sample size needed for 32 items is 320 . Moreover, to overcome the non-response bias, this sample size is increased to 500 (Sakaran, 2003). This study also validated the sample size using power analysis based on Hair et al. (2017) recommendation. Based on $\mathrm{G}^{*}$ Power analysis, suggestion 129 respondents is suitable as the minimum sample size for five predictors (Faul et al., 2007). Therefore 467 surveys are sufficient, with a power of above 0.80 per cent (Hair et al., 2019).

\section{Results}

\subsection{Respondents' Demographic Profiles}

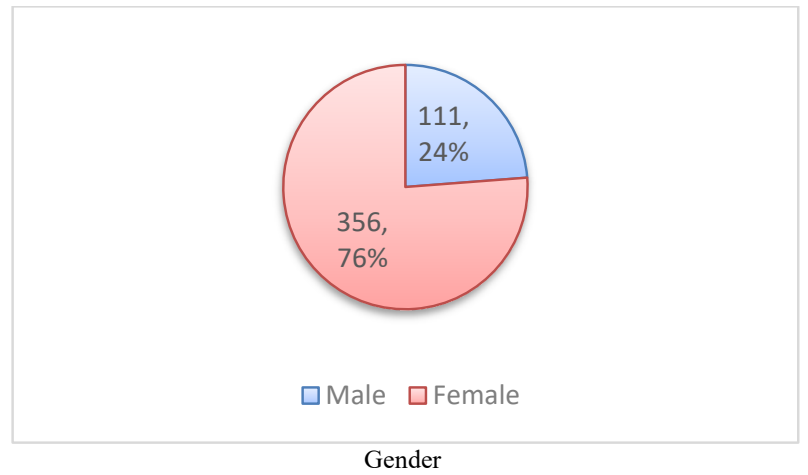

Gender

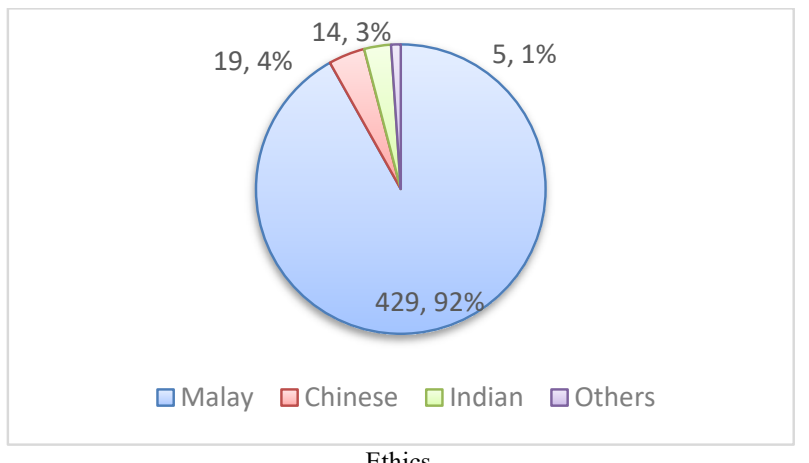

Ethics 

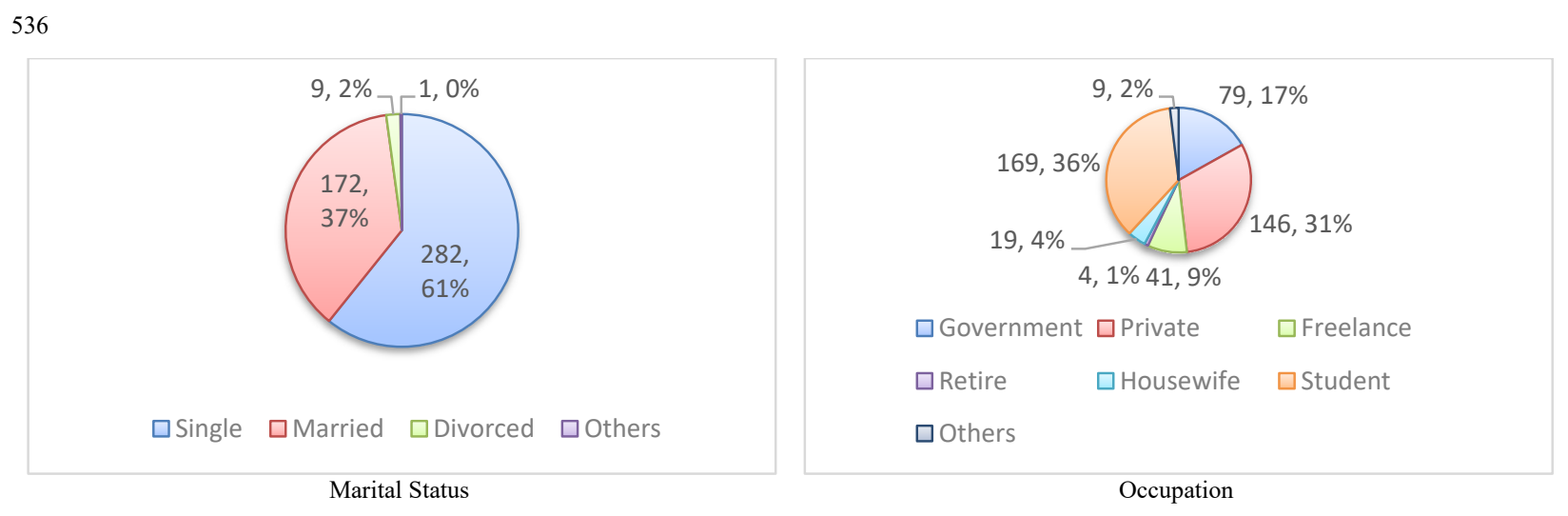

Fig. 2. Result of Demography Profile of Respondents

Fig. 2 provides detail on respondent profiles on herbal buyers. Total of 467 respondents agreed to participate, which is equivalent to $93 \%$. Table 1 shows that most respondents are female, $356(76.2 \%)$ and $111(23.8 \%)$ males. The Ethnic profile shows that the overall respondent is Malay which is $429(91.9 \%)$, followed by Chinese $19(4.1 \%)$, Indian $14(3.0 \%)$ and other 5 (1.1\%). The higher portion of status is single $282(60.4 \%)$, followed by marriage respondents $175(37.5 \%)$, divorce $9(1.9 \%)$, and others $1(0.2 \%)$. Finally, most respondents working in the private sector, $146(31.3 \%)$, followed by government sector 79 (16.9\%). Freelance $41(8.8 \%)$, Retire 4 (0.9\%), Student $169(36.2 \%)$, Others $9(1.9 \%)$.

\subsection{Data Analysis}

This study uses two statistical software, namely Statistical Package for Social Sciences (SPSS-23) and SmartPLS. SPSS was used to descriptive analysis and SmartPLS has chosen to evaluate the study's measurement and structural model because it is aligned with its goal. WebPower analysis confirmed Mardia's multivariate skewness (Skewness $=2.377, \mathrm{p}<0.01)$ and multivariate kurtosis (Kurtosis $=41.014, \mathrm{p}<0.01$ ). It indicates that the data are slightly non-normal. Thus, SmartPLS is suitable for this study. This study uses a single source; therefore, it might suffer from a common method variance issue (Mackenzie \& Podsakoff, 2003; Podsakoff et al., 2011; Podsakoff et al., 2003, 2012). Hence to rectify this issue, this study applied two methods: procedural using different scales between exogenous and endogenous variables using a 5-point and 7-point Likert scale. The second method is the statistical approach using collinearity analysis. It was essential to ensure that it did not have any issues with multicollinearity. According to Diamantopoulos and Siguaw (2006), the model's VIF values must be less than 3.3 to ensure that multicollinearity was not an issue in the study. Therefore, the study's VIF values were less than 3.3, indicating that multicollinearity was not a major concern (Table 1).

Table 1

The Result of Multicollinearity test using Variance Inflation Factor (VIF)

\begin{tabular}{ccccc}
\hline Attitude & Mass Media Influence & Product Safety & Social influence & Purchase Behaviour \\
\hline 2.245 & 1.601 & 1.597 & 2.821 & 1.731 \\
\hline
\end{tabular}

Table 2 shows the result of a multicollinearity test using Variance Inflation Factor (VIF). This study found that all VIF values are lower than 3.3, which indicated this study did not suffer from the CMV issue (Kock, 2015; Podsakoff et al., 2003). Furthermore, this study utilised the Partial Least Square (PLS) analysis to evaluate the research model using the SmartPLS 3.3.3 software developed by Ringle et al. (2015), which is a variance-based structural equation modelling (SEM). In addition, this study is to predict the relationship between variables; therefore, Partial Least Square is a better choice than covariance-based SEM (Hair et al., 2014). Moreover, Smart PLS is ideal for data that does not fulfil the normality requirements. Based on Anderson \& Gerbing (1988), two-stage analytical procedures to analyse the measurement model's validity and reliability and check the structural model. And to test the significance of path coefficients between exogenous and endogenous constructs, this study used the bootstrapping procedure (Hair et al., 2019).

\subsection{Measurement Model}

In the first stage analysis procedure, the study validated the measurement model before proceeding to the second stage, which is the structural model. The measurement model in this study is validated through twofold convergent and discriminant validities. Further, convergent validity must be established to ensure that multiple items measure the same constructs (Hair et al., 2019; Hulland et al., 2018; Syima et al., 2019). If the loading and Average Variance Extracted (AVE) values are greater than 0.5 , and the composite reliability value is greater than 0.7 , convergent validity has been fulfilled (Hair et al., 2017). 
Table 2

The Result of Construct Validity and Reliability

\begin{tabular}{|c|c|c|c|c|}
\hline Construct & Item & Loading & CR & AVE \\
\hline \multirow{5}{*}{ Attitude } & A1 & 0.86 & \multirow{5}{*}{0.94} & \multirow{5}{*}{0.75} \\
\hline & A2 & 0.88 & & \\
\hline & A3 & 0.85 & & \\
\hline & A4 & 0.84 & & \\
\hline & A5 & 0.90 & & \\
\hline \multirow{4}{*}{ Mass Media Influence } & MMI1 & 0.85 & \multirow{4}{*}{0.91} & \multirow{4}{*}{0.72} \\
\hline & MM12 & 0.88 & & \\
\hline & MMI3 & 0.89 & & \\
\hline & MMI4 & 0.76 & & \\
\hline \multirow[t]{2}{*}{ Product Safety } & PS1 & 0.82 & \multirow[t]{2}{*}{0.83} & \multirow[t]{2}{*}{0.72} \\
\hline & PS2 & 0.87 & & \\
\hline \multirow{4}{*}{ Purchase Behaviour } & PB1 & 0.84 & \multirow{4}{*}{0.89} & \multirow{4}{*}{0.66} \\
\hline & PB2 & 0.82 & & \\
\hline & PB3 & 0.80 & & \\
\hline & PB4 & 0.80 & & \\
\hline \multirow{4}{*}{ Social Influence } & SI1 & 0.87 & \multirow{4}{*}{0.93} & \multirow{4}{*}{0.78} \\
\hline & SI2 & 0.88 & & \\
\hline & $\mathrm{SI} 3$ & 0.89 & & \\
\hline & SI5 & 0.89 & & \\
\hline
\end{tabular}

Note: $\mathrm{AVE}=$ average variance extracted, $\mathrm{CR}=$ composite reliability PS3, PS4 was deleted due to low loading

Table 2 displays the result of construct validity and reliability. This study found that all value of loading, Composite Reliability (CR) and AVE values have been met the threshold levels. Next, Hair et al., (2020) suggested the second procedure is the discriminant analysis determined through Heterotrait-Monotrait (HTMT). This procedure is based on the recommendation from Franke and Sarsted (2019). Furthermore, this procedure is considered superior compared to the Fornell-Larcker criterion. The discriminant validity is confirmed if the Heterotrait-Monotrait (HTMT) values are lower than 0.85 .

Table 3

The Result of Discriminant Validity using Heterotrait-Monotrait (HTMT)

\begin{tabular}{lccccc}
\hline & Attitude & Mass Media & Product Safety & Purchase Behaviour & Social Influence \\
\hline Attitude & & & & & \\
Mass Media & 0.66 & & & & \\
Product Safety & 0.78 & 0.58 & & & \\
Purchase Behaviour & 0.71 & 0.54 & 0.62 & 0.67 & \\
Social Influence & 0.76 & 0.61 & 0.75 & 0.67 \\
\hline
\end{tabular}

Table 3 shows that all HTMT values are lower than 0.85, it means that the studied variables fulfil the discriminant validity.

\subsection{Structural Model}

In the second stage, the analysis procedure is the structural model; at this stage, a 95 per cent confidence interval was applied with 5,000 bootstrapping (Hair et al., 2019). The result of hypothesis testing, as seen in Table 4 below:

Table 4

The Result of Hypothesis Testing

\begin{tabular}{ccccccccc}
\hline Path Analysis & Beta & SE & t-value & Sig. & LL & UL & $\mathrm{R}^{2}$ & $f^{2}$ \\
\hline Mass Media Influence $\rightarrow$ Attitude & 0.587 & 0.034 & 17.155 & 0.000 & 0.527 & 0.639 & 0.344 & 0.525 \\
Mass Media Influence $\rightarrow$ Social Influence & 0.545 & 0.039 & 13.962 & 0.000 & 0.477 & 0.612 & 0.297 & 0.422 \\
Mass Media Influence $\rightarrow$ Product Safety & 0.418 & 0.042 & 10.014 & 0.000 & 0.351 & 0.486 & 0.175 & 0.212 \\
Attitude $\rightarrow$ Purchase Behaviour & 0.393 & 0.062 & 6.385 & 0.000 & 0.293 & 0.497 & - & 0.095 \\
Social Influence $\rightarrow$ Purchase Behaviour & 0.231 & 0.066 & 3.523 & 0.000 & 0.121 & 0.338 & 0.416 & 0.034 \\
Product Safety $\rightarrow$ Purchase Behaviour & 0.083 & 0.047 & 1.741 & 0.041 & 0.006 & 0.165 & & 0.007 \\
\hline
\end{tabular}

Table 4 indicates that Mass Media has a significant positive effect on Attitude, Social Influence and Product Safety. The value of the standardized regression coefficient of Mass Media to Attitude was 0.587, t-value is 17.155 and significant at the level $\mathrm{p}<0.001$. It means that by assuming an increase in Mass Media of 1 percent would give an effect on increasing Attitude by as much as 58.7 percent. Further, Mass Media to Social Influence was 0.545, t-value is 13.962 and significant at the level $p<$ 0.001. It means that by assuming an increase in Mass Media of 1 percent would give an effect on increasing Social Influence by as much as 54.5 percent. Also, Mass Media to Product Safety was 0.418 , t-value is 10.014 and significant at the level $p<$ 0.001 . It means that by assuming an increase in Mass Media of 1 percent would give an effect on increasing Product Safety by as much as 41.8 percent. 
Besides that, this study also examines the effect of Attitude, Social Influence and Product Safety on Purchase Behaviour. The result shows that Attitude, Social Influence and Product Safety have a significant positive effect on Purchase Behaviour. The value of the standardized regression coefficient of Attitude to Purchase Behaviour was 0.393 , t-value is 6.385 and significant at the level $\mathrm{p}<0.001$. It means that by assuming an increase in Attitude of 1 percent would give an effect on increasing Purchase Behaviour by as much as 39.3 percent. Further, the value of the standardized regression coefficient of Social Influence on Purchase Behaviour was 0.231 , $t$-value is 3.523 and significant at the level $p<0.001$. It means that by assuming an increase in Social Influence of 1 percent would give an effect on increasing Purchase Behaviour by as much as 23.1 percent. Lastly, the value of the standardized regression coefficient of Product Safety on Purchase Behaviour was 0.083, t-value is 1.741 and significant at the level $\mathrm{p}<0.05$. It means that by assuming an increase in Product Safety of 1 percent would give an effect on increasing Purchase Behaviour by as much as 8.3 percent. As a result, this study confirmed that the proposed hypotheses i.e., H1, H2, H3, H4, H5 and H6 were supported.

In addition, this study reported the value of determination coefficient $\left(\mathrm{R}^{2}\right)$, and effect size $\left(f^{2}\right)$. The $\mathrm{R}^{2}$ values were $34 \%$ for attitude, $30 \%$ for social influence, $18 \%$ for product safety, and this shows that attitude, social influence, and product explain $42 \%$ of the Purchase Behaviour. Meanwhile, to measure the effect size, the study used Cohen (1988) guidelines, $f^{2} \geq 0.02$ (Small), $f^{2} \geq 0.15$ (Medium), and $f^{2} \geq 0.35$ (Large). The analysis shows that three of six constructs have the following effect size, attitude 0.524 , social influence 0.422 , product safety 0.211 . And this indicates that mass media influence has the biggest effect size on attitude. The next findings for the purchase behaviour show that attitude with a small effect size (0.094) has the biggest effect on purchase behaviour.

\section{Discussion}

This study investigates the structural relationship of mass media on attitudes, social influences, product safety and its impact on purchase behaviour. The analysis results show that the influence of mass media has a positive relationship with attitude $\mathrm{H} 1$, social influence H2, product safety H3. The findings of these three hypotheses prove that the impact of the mass media is significant on these variables. The more positive the information presented by the mass media will make the attitude of buyers more positive in influencing the purchase of herbal products. The finding of several suggested a strong relationship between mass media influence and consumer attitude (Borhan et al., 2017; Khalek, 2014; Sumngern et al., 2011). In addition, the effects of the social influence will give a positive statement or opinion to the people closest to the individual known as the reference group, which plays a vital role in influencing them to use herbal products. A similar finding has also been proved by Ismail (2012) in which mass media are significantly affecting Social Influence. Moreover, the influence of the mass media on product safety is also significant because the mass media can be used as channel-to-channel information so that buyers are aware of the content of the mixture of ingredients used during the manufacturing process of herbal products. In addition to ensuring that consumers are safe and confident in herbal products. The influence of the mass media is seen as essential to convey accurate product safety information, and the result is similar to the previous finding (Chen, 2008; Ismail \& Mokhtar, 2015b; Napoli, 2010)

The study's findings in hypothesis 4 concluded that the more positive the attitude of buyers towards herbal products, the more positive the desire to buy those products. Therefore, marketers should be aware that the consumer attitude is vital in stimulating their desire to purchase. A positive attitude can increase confidence and evaluate the effectiveness of herbal products in influencing the purchase of such products. The importance of attitudes towards herbal products will help marketers formulate promotional strategies to convince consumers to buy their products (Chaniotakis et al., 2010; Maichum et al., 2016; Rahnama, 2016; Syima et al., 2019). Hypothesis 5 shows the effect of social influence was found to influence purchase behaviour. And this suggests that social influences are capable of changing consumers' feelings, attitudes, and behaviours. The study results have indicated that social influences have influenced the purchase of herbal products and suggest that consumers or buyers of herbal products refer to other individuals before purchasing (Hadiwijaya, 2015; Ismail \& Mokhtar, 2016; Policarpo \& Aguiar, 2020). Further hypothesis 6 finds that product safety can influence purchases behaviour and clearly shows that customers prefer to buy herbal products when they are confident with the product safety and can lead them to purchase the herbal products. Furthermore, the herbal products available in Malaysia are indeed easy to obtain and can be used without the supervision of a physician. From a practical point of view, product safety is essential to consumers because they feel that these herbal products are organic and natural, safe, have no side effects, and do not need special supervision.

\section{Conclusion}

In conclusion, this study has successfully identified the determinant factors of Attitude, Social Influence, Product Safety and Purchase Behaviour. Also, this study has enhanced the understanding of the factors that influence the purchase behaviour of herbal products. Furthermore, the findings will be helpful to entrepreneurs interested in knowing the fundamental factors that influence the purchase behaviour of herbal products and benefit when drawing up their marketing strategy. The result suggests a positive attitude towards herbal products play an essential role in influencing purchase behaviour. Meanwhile, the analysis showed that the relationship between social influence and purchase behaviour was significantly positive; this finding was also supported by several previous studies that showed that social influence plays a vital role in influencing purchase behaviour. Product safety is also an important determinant to purchase behaviour due to its ability to determine whether a product is safe 
to be bought and used. To ensure that there are no side effects related to the use of herbal products among consumers, entrepreneurs should be more sensitive to the mixture of ingredients used during the manufacturing process so that it does not harm the consumers.

Furthermore, the results of this study have also revealed that in deciding to use herbal products, the process has a lot of control of the will, where consumers need a lot of resources such as time, information, and the level of confidence in the product before they can make the right decision. In addition, the Government can increase buyers' awareness about the use of unregistered products to avoid the possibility of side effects due to the use of herbal products. In addition, to overcome the issue of herbal product toxicity, the Government can monitor advertisements claims of product effectiveness without solid scientific facts, by-product entrepreneurs. Furthermore, the demographic variables such as gender, ethnicity, status, and occupation make the customer's mindsets different from one another, which can help entrepreneurs identify the right products and target groups and be more competitive.

\section{Acknowledgement}

We would like to thank the Centre for Research and Innovation Management (CRIM), Universiti Malaysia Terengganu that has supported this research through Grant No. 55172/TAPE-RG, publication and everyone who has volunteered to participate in this research.

\section{References}

Abdualmjid, R. J., \& Sergi, C. (2013). Hepatotoxic botanicals-an evidence-based systematic review. Journal of Pharmacy \& Pharmaceutical Sciences, 16(3), 376-404.

Abdullah, N., \& Salleh, S. (2010). Factors Related to the Use of Herbal Products and Derivatives from Consumers ' Perspective in Kota Kinabalu, Sabah: An Initial Study. 3(1), 143-154.

Adam, K., Agnieszka, B., Kamila, B., \& Katarzyna, K. B. (2017). Use of the herbal otc products and dietary supplements by patients receiving chemotherapy: Survey-based study. Indian Journal of Pharmaceutical Education and Research, 51(4), S675-S678. https://doi.org/10.5530/ijper.51.4s.98

Ahmad, F., Zaidi, M. A. S., Sulaiman, N., \& Abdul Majid, F. A. (2015). Issues and Challenges in the Development of the Herbal Industry in Malaysia. Persidangan Kebangsaan Ekonomi Malaysia Ke-10 (PERKEM 10), Kekayaan Terangkum Teras Pembangunan Lestari, 10(September), 227-238.

Ajzen, I. (1985). From intentions to actions: A Theory of Planned Behavior. In Action control (SSSP Sprin, pp. 11-39). Springer,Berlin,Heidelberg. https://doi.org/https://doi.org/10.1007/978-3-642-69746-3_2

Ajzen, I. (2001). Nature and Operation of Attitude. Annual Review of Psychology, 52, 27-58.

Ajzen, I. (2012a). Attitudes and Persuasion. The Oxford Handbook of Personality and Social Psychology. https://doi.org/10.1093/oxfordhb/9780195398991.013.0015

Ajzen, I. (2012b). Martin Fishbein's Legacy. The ANNALS of the American Academy of Political and Social Science, 640(1), 11-27. https://doi.org/10.1177/0002716211423363

Ajzen, I., \& Fishbein, M. (1980). Understanding attituted and predicting social behavior. Prentice Hall.

Ajzen, I., \& Fishbein, M. (2005). The Influence of Attitudes on Behavior. Handbook of Attitudes and Attitude Change: Basic Principles, 173-221. https://doi.org/10.1080/00224545.1956.9921907

Ajzen, I., \& Madden, T. J. (1986). Prediction of goal-directed behavior: Attitudes, intentions, and perceived behavioral control. Journal of Experimental Social Psychology, 22(5), 453-474. https://doi.org/10.1016/0022-1031(86)90045-4

Alexieva, I. N., Popova, A. T., \& Mihaylova, D. S. (2020). Trends in herbal usage - A survey study. Food Research, 4(2), 500-506. https://doi.org/10.26656/fr.2017.4(2).346

Alzubaidi, H., Slade, E. L., \& Dwivedi, Y. K. (2020). Examining antecedents of consumers' pro-environmental behaviours: TPB extended with materialism and innovativeness. Journal of Business Research, February 2019, 1-15. https://doi.org/10.1016/j.jbusres.2020.01.017

Anderson, J. C., \& Gerbing, D. W. (1988). Structural equation modeling in practice: A review and recommended two-step approach. Psychological Bulletin, 103(3), 411.

Ang, H.-H., Lee, K.-L., \& Kiyoshi, M. (2003). Analysis of lead content in herbal preparations in Malaysia. Human \& Experimental Toxicology, 22(8), 445-451. https://doi.org/10.1191/0960327103ht382oa

Ang, H.-H., Lee, K.-L., \& Kiyoshi, M. (2005). Determination of Lead in Smilax Luzonensis Herbal Preparations in Malaysia. International Journal of Toxicology, 24(3), 165-171. https://doi.org/10.1080/10915810590952942

Archer, E. L., \& Boyle, D. K. (2008). Herb and supplement use among the retail population of an independent, urban herb store. Journal of Holistic Nursing : Official Journal of the American Holistic Nurses' Association, 26(1), 27-35; quiz, 3840. https://doi.org/10.1177/0898010107305326

Arli, D., Tan, L. P., Tjiptono, F., \& Yang, L. (2018). Exploring consumers' purchase intention towards green products in an emerging market: The role of consumers' perceived readiness. International Journal of Consumer Studies, 42(4), 389401. https://doi.org/10.1111/ijcs. 12432

Azjen, I. (1991). The theory of planned behavior. Organizational Behavior and Human Decision Processes, 50(2), $179-211$. https://scholar.google.com/scholar?hl=en\&as_sdt=0\%2C5\&q=Azjen $+1991 \& b t n G=$ 
Bagherzad, A., Chavosh, A., \& Soheilirad, S. (2011). the Impact of Culture on Young Consumer ' S Intention Towards Online Shoppingh in Malaysia. International Conference on Business and Economics Research, 1, 120-123.

Bai, L., Wang, M., \& Gong, S. (2019). Understanding the antecedents of organic food purchases: The important roles of beliefs, subjective norms, and identity expressiveness. Sustainability (Switzerland), 11(11). https://doi.org/10.3390/su11113045

Balachandran, I., \& Hamzah, I. B. (2017). The Influence of Customer Satisfaction on Ride-Sharing Services in Malaysia. International Journal of Accounting \& Business Management, 5(2), 184-196. https://doi.org/10.1098/rstb.2013.0388

Bandaranayake, W. M. (2006). Quality Control, Screening, Toxicity, and Regulation of Herbal Drugs. In Modern Phytomedicine: Turning Medicinal Plants into Drugs. https://doi.org/10.1002/9783527609987.ch2

Banu Rekha, M., \& Gokila, K. (2015). A study on consumer awareness,attitude and preference towards herbal cosmetic products with special reference to Coimbatore city. International Journal of Interdisciplinary and Multidisciplinary Studies. https://doi.org/10.9790/487X-17735054

Barnes, J. (2003). Quality, efficacy and safety of complementary medicines: Fashions, facts and the future. Part II: Efficacy and safety. British Journal of Clinical Pharmacology, 55(4), 331-340. https://doi.org/10.1046/j.1365-2125.2003.01811.x

Basha, M. B., \& Lal, D. (2019). Indian consumers' attitudes towards purchasing organically produced foods: An empirical study. In Journal of Cleaner Production (Vol. 215, pp. 99-111). https://doi.org/10.1016/j.jclepro.2018.12.098

Belland, B. R., Walker, A. E., Kim, N. J., \& Lefler, M. (2017). Synthesizing Results From Empirical Research on ComputerBased Scaffolding in STEM Education: A Meta-Analysis. Review of Educational Research, 87(2), 309-344. https://doi.org/10.3102/0034654316670999

Bellikci-Koyu, E., Şarer-Yürekli, B. P., Seçkiner, S., Özdemir, N., \& Buyuktuncer, Z. (2020). Use of herbal products for weight loss in Turkey. Progress in Nutrition, 22(3), 1-8. https://doi.org/10.23751/pn.v22i3.8095

Bent, S. (2008). Herbal medicine in the United States: Review of efficacy, safety, and regulation - Grand Rounds at University of California, San Francisco Medical Center. Journal of General Internal Medicine, 23(6), 854-859. https://doi.org/10.1007/s11606-008-0632-y

Borhan, M. N., Ibrahim, A. N. H., Syamsunur, D., \& Rahmat, R. A. (2017). Why Public Bus is a Less Attractive Mode of Transport: A Case Study of Putrajaya, Malaysia. Periodica Polytechnica Transportation Engineering, 47(1), 82-90. https://doi.org/10.3311/pptr.9228

Boullata, J. I., \& Nace, a M. (2000). Safety issues with herbal medicine. Pharmacotherapy, 20(3), 257-269.

Brown, B. S., Emmett, D., \& Chandra, A. (2009a). Attitudes and behavior of african-americans regarding the consumption of herbal products - An exploratory study. Journal of Hospital Marketing and Public Relations, 19(1), 40-51. https://doi.org/10.1080/15390940802581655

Brown, B. S., Emmett, D., \& Chandra, A. (2009b). Attitudes and Behavior of African-Americans Regarding the Consumption of Herbal Products - An Exploratory Study. Journal of Hospital Marketing \& Public Relations, 19(1), 40-51. https://doi.org/Article

Bukhari, S. F. H., Woodside, F. M., Hassan, R., Hussain, S., \& Khurram, S. (2020). Exploring the motives behind the purchase of western imported food products. A phenomenological study from a Muslim-dominated region. Journal of Islamic Marketing. https://doi.org/10.1108/JIMA-05-2020-0139

Calitz, C., Du Plessis, L., Gouws, C., Steyn, D., Steenekamp, J., Muller, C., \& Hamman, S. (2015). Herbal hepatotoxicity: Current status, examples, and challenges. Expert Opinion on Drug Metabolism and Toxicology, 11(10), 1551-1565. https://doi.org/10.1517/17425255.2015.1064110

Chaloupkova, P., Petrtyl, M., Verner, V., \& Kokoska, L. (2020). Dietary supplements versus functional foods: consumers' attitudes to their consumption. British Food Journal, 122(12), 3853-3868. https://doi.org/10.1108/BFJ-10-2019-0767

Chaniotakis, I. E., Lymperopoulos, C., \& Soureli, M. (2010). Consumers' intentions of buying own-label premium food products. The Journal of Product and Brand Management, 19(5), 327-334. https://doi.org/http://0dx.doi.org.medina.uco.es/10.1108/10610421011068568

Chaudhuri, A., \& Holbrook, M. B. (2001). The chain of effects from brand trust and brand affect to brand performance: The role of brand loyalty. Journal of Marketing, 65(2), 81-93. https://doi.org/10.1509/jmkg.65.2.81.18255

Cheah, J. H., Ting, H., Cham, T. H., \& Memon, M. A. (2019). The effect of selfie promotion and celebrity endorsed advertisement on decision-making processes: A model comparison. Internet Research. https://doi.org/10.1108/IntR-122017-0530

Chen, M. (2008). Consumer trust in food safety--a multidisciplinary approach and empirical evidence from Taiwan. Risk Analysis : An Official Publication of the Society for Risk Analysis, 28(6), 1553-1569. https://doi.org/10.1111/j.15396924.2008.01115.x

Conner, M., Kirk, S. F., Cade, J. E., \& Barrett, J. H. (2001). Why do women use dietary supplements? The use of the theory of planned behaviour to explore beliefs about their use. Social Science \& Medicine, 52, 621-633. https://doi.org/10.1016/S0277-9536(00)00165-9

Corey, R., Werner, K. T., Singer, A., Moss, A., Smith, M., Noelting, J., \& Rakela, J. (2016). Acute liver failure associated with Garcinia cambogia use. Annals of Hepatology, 15(1), 123-126. https://doi.org/10.5604/16652681.1184287

Crescioli, G., Lombardi, N., Bettiol, A., Marconi, E., Risaliti, F., Bertoni, M., Menniti Ippolito, F., Maggini, V., Gallo, E., Firenzuoli, F., \& Vannacci, A. (2018). Acute liver injury following Garcinia cambogia weight-loss supplementation: case series and literature review. Internal and Emergency Medicine, 13(6), 857-872. https://doi.org/10.1007/s11739-018-18804 
Dailey, R. K., Neale, A. V., Northrup, J., West, P., \& Schwartz, K. L. (2003). Herbal product use and menopause symptom relief in primary care patients: a MetroNet study. Journal of Women's Health, 12(7), 633-641. https://doi.org/10.1089/154099903322404285

Dangelico, R. M., \& Vocalelli, D. (2017). "Green Marketing”: An analysis of definitions, strategy steps, and tools through a systematic review of the literature. Journal of Cleaner Production, 165, 1263-1279. https://doi.org/10.1016/j.jclepro.2017.07.184

Dhir, A., Sadiq, M., Talwar, S., Sakashita, M., \& Kaur, P. (2021). Why do retail consumers buy green apparel? A knowledgeattitude-behaviour-context perspective. Journal of Retailing and Consumer Services, 59(October), 102398. https://doi.org/10.1016/j.jretconser.2020.102398

Diamantopoulos, A., \& Siguaw, J. A. (2006). Formative versus reflective indicators in organizational measure development: A comparison and empirical illustration. British Journal of Management, 17(4), 263-282. https://doi.org/10.1111/j.14678551.2006.00500.x

Douros, A., Bronder, E., Andersohn, F., Klimpel, A., Kreutz, R., Garbe, E., \& Bolbrinker, J. (2016). Herb-induced liver injury in the berlin case-control surveillance study. International Journal of Molecular Sciences, 17(1), 1-11. https://doi.org/10.3390/ijms17010114

Ekor, M. (2014). The growing use of herbal medicines: Issues relating to adverse reactions and challenges in monitoring safety. Frontiers in Neurology, 4 JAN(January), 1-10. https://doi.org/10.3389/fphar.2013.00177

El-Dahiyat, F., Rashrash, M., Abuhamdah, S., Abu Farha, R., \& Babar, Z. U. D. (2020). Herbal medicines: A cross-sectional study to evaluate the prevalence and predictors of use among Jordanian adults. Journal of Pharmaceutical Policy and Practice, 13(1), 1-9. https://doi.org/10.1186/s40545-019-0200-3

Ertz, M., Karakas, F., \& Sarigöllü, E. (2016). Exploring pro-environmental behaviors of consumers: An analysis of contextual factors, attitude, and behaviors. Journal of Business Research, 69(10), 3971-3980. https://doi.org/10.1016/j.jbusres.2016.06.010

Fandos, C., \& Flavián, C. (2006). Intrinsic and extrinsic quality attributes, loyalty and buying intention: an analysis for a PDO product. British Food Journal, 108, 646-662. https://doi.org/10.1108/00070700610682337

Fanny Putera Perdana, F., Jan, M. T., Altunişik, R., Jaswir, I., \& Kartika, B. (2019). the Role of Halal Certification on Purchase Intention Towards Food Products From Mena Countries: a Sem Study. Journal of Islamic Monetary Economics and Finance, 5(1), 63-88. https://doi.org/10.21098/jimf.v5i1.1048

Fishbein, M., \& Ajzen, I. (1975). Belief, Attitude, Intention and Behaviour: The Introduction to Theory and Research. Addison-Wesley Publushing Company, Inc.

Fleșeriu, C., Cosma, S. A., \& Bocăneț, V. (2020). Values and Planned Behaviour of the Romanian Organic Food Consumer. Sustainability, 12(5), 1722. https://doi.org/10.3390/su12051722

Franke, G., \& Sarstedt, M. (2019). Heuristics versus statistics in discriminant validity testing: a comparison of four procedures. Internet Research, 29(3), 430-447. https://doi.org/10.1108/IntR-12-2017-0515

Global Industry Analysts.Inc. (2020). Global Industry Analysts.Inc USA.

Goh, C. F., Chan, M. Y., Ali, A. M., \& Rashid, S. M. (2019). The complementary and alternative medicine (CAM) product information brochure: How is generic structure used to persuade potential users? GEMA Online Journal of Language Studies, 19(4), 219-242. https://doi.org/10.17576/gema-2019-1904-12

Goh, S. K., \& Balaji, M. S. (2016). Linking green skepticism to green purchase behavior. Journal of Cleaner Production, 131, 629-638. https://doi.org/10.1016/j.jclepro.2016.04.122

Gok, I., \& Ulu, E. K. (2019). Functional foods in Turkey: marketing, consumer awareness and regulatory aspects. Nutrition and Food Science, 49(4), 668-686. https://doi.org/10.1108/NFS-07-2018-0198

Grunert, K. G. (2005). Food quality and safety: Consumer perception and demand. European Review of Agricultural Economics, 32(3), 369-391. https://doi.org/10.1093/eurrag/jbi011

Hadiwijaya, K. K. (2015). Consumer Intention of Purchasing Original and Counterfeit Products ; a Case Study of Louis Vuitton Wallet. IBuss Management, 3(2), 272-284.

Hair, J. F., Hult, G. T. M., Ringle, C. M., \& Sarstedt, M. (2014). Partial least squares structural equation modeling (PLSSEM). In Sage Publisher.

Hair, J. F., Risher, J. J., Sarstedt, M., \& Ringle, C. M. (2019). When to use and how to report the results of PLS-SEM. European Business Review, 31(1), 2-24. https://doi.org/10.1108/EBR-11-2018-0203

Hair, Joe F., Howard, M. C., \& Nitzl, C. (2020). Assessing measurement model quality in PLS-SEM using confirmatory composite analysis. Journal of Business Research, 109(November 2019), 101-110. https://doi.org/10.1016/j.jbusres.2019.11.069

Hair, Joseph F., Hult, G. T. M., Ringle, C. M., Sarstedt, M., \& Thiele, K. O. (2017). Mirror, mirror on the wall: a comparative evaluation of composite-based structural equation modeling methods. Journal of the Academy of Marketing Science, 45(5), 616-632. https://doi.org/10.1007/s11747-017-0517-x

Haque, A., Anwar, N., Kabir, S., Yasmin, F., Tarofder, A. K., \& Mhm, N. (2020). Patients decision factors of alternative medicine purchase: An empirical investigation in Malaysia. International Journal of Pharmaceutical Research, 12(3), 614-622. https://doi.org/10.31838/ijpr/2020.12.03.090

Haque, A., Anwar, N., Tarofder, A. K., Ahmad, N. S., \& Sharif, S. R. (2018). Muslim consumers' purchase behavior towards halal cosmetic products in Malaysia. Management Science Letters, 8(12), 1305-1318. https://doi.org/10.5267/j.msl.2018.9.009 
Hashjin, S. T., VakilaRoaia, Y., \& Hemati, M. (2014). The Study of Factors Influencing the Accepting of Internet Banking (Case Study : Bank Sepahin Alborz Province ). Arabian Journal of Business and Management Review (OMAN Chapter), 3(7), 85-98.

Hashmi, U., Huong, N. T., \& Wee, C. S. (2012). Key Factors Affecting Consumer Purchase Intention a Study of Safe Vegetable in Ho Chi Minh City, Vietnam. University of Economics Ho Chi Minh City: International School of Business, 1(1), 1-68.

Ho, T. C. F., Ahmad, N. H., \& Ramayah, T. (2016). Competitive Capabilities and Business Performance among Manufacturing SMEs: Evidence from an Emerging Economy, Malaysia. Journal of Asia-Pacific Business, 17(1), 37-58. https://doi.org/10.1080/10599231.2016.1129263

Holt, G. A., \& Chandra, A. (2002). Herbs in the Modern Healthcare Environment - an Overview of Uses, Legalities, and the Role of the Healthcare Professional. Clinical Research and Regulatory Affairs, 19(1), 83-107.

Huang, J., Tao, G., Liu, J., Cai, J., \& Huang, Z. (2020). Current Prevention of COVID-19: Natural Products and Herbal Medicine. 11(October), 1-18. https://doi.org/10.3389/fphar.2020.588508

Hulland, J., Baumgartner, H., \& Smith, K. M. (2018). Marketing survey research best practices: evidence and recommendations from a review of JAMS articles. Journal of the Academy of Marketing Science, 46(1), 92-108.

Hung, M. F., Chang, C. T., \& Shaw, D. (2019). Individuals' intentions to mitigate air pollution: Vehicles, household appliances, and religious practices. Journal of Cleaner Production, 227, 566-577.

Hussin, A. (2001). Adverse effects of herbs and drug-herbal interactions. Malaysian Journal of Pharmacy, 1(2), 39-44.

Ibrahim, R., Saputra, J., Ali, S. N. M., Dagang, M. M., \& Bakar, A. A. (2019). Organizational justice and job satisfaction among Malaysian workers. Opcion, 35(89), 494-513.

Ismail, M. (2012). Factor Influencing Consumers' Acceptance of Mobile Marketing Services. Universiti Utara Malaysia.

Ismail, S., \& Mohd Mokhtar, S. S. (2016a). Linking attitude to actual purchase of herbal product in Malaysia: The moderating role of perceived risk. Journal of Asian Business Strategy, 6(2), 22-30.

Ismail, S., \& Mohd Mokhtar, S. S. (2016b). Linking Attituded to Actual Purchase of Herbal Product in Malaysia: The Moderating Role of Perceived Risk. Journal of Asian Business Strategy, 6(2), 22-30.

Ismail, S., \& Mohd Mokhtar, S. S. (2017). Corak Pembelian Product Berasaskan Herba Di Malaysia (Buying Patterns of Herbal-Based Products in Malaysia). International Journal Management Studies, 24(1), 91-118.

Ismail, S., \& Mokhtar, S. S. M. (2015a). Moderating effect of perceived risk on the relationship between product safety and intention. Management Science Letters, 5(2), 205-212. https://doi.org/10.5267/j.msl.2014.12.016

Ismail, S., \& Mokhtar, S. S. M. (2015b). The antecedents of herbal product actual purchase in Malaysia. International Journal of Business and Technopreneurship, 5(3), 343-355. https://doi.org/10.5267/j.msl.2015.5.011

Ismail, S., \& Mokhtar, S. S. M. (2016). Moderating Role of Perceived Benefit on the Relationship between Attitude and Actual Purchase. International Review of Management and Marketing, 6, 22-28.

Izuagbe, R., Ifijeh, G., Izuagbe-Roland, E. I., Olawoyin, O. R., \& Ogiamien, L. O. (2019). Determinants of perceived usefulness of social media in university libraries: Subjective norm, image and voluntariness as indicators. Journal of Academic Librarianship, 45(4), 394-405. https://doi.org/10.1016/j.acalib.2019.03.006

Jaiswal, D., \& Kant, R. (2018). Green purchasing behaviour: A conceptual framework and empirical investigation of Indian consumers. Journal of Retailing and Consumer Services, 41(November 2017), 60-69.

Jantan, I. (2006). The Scientific Values of Malaysian Herbal Products. 4(1), 59-70.

Judge, M., Warren-Myers, G., \& Paladino, A. (2019). Using the theory of planned behaviour to predict intentions to purchase sustainable housing. Journal of Cleaner Production, 215, 259-267.

Karim, M. S. A., Nasouddin, S. S., Othman, M., Mohd Adzahan, N., \& Hussin, S. R. (2011). Consumers' knowledge and perception towards Melicope ptelefolia (Daun Tenggek Burung): A preliminary qualitative study. International Food Research Journal, 18(4), 1481-1488.

Karlowicz-Bodalska, K., Miśkiewicz, K., Kurpas, D., Han, S., Kowalczyk, A., Marciniak, D., Dryś, A., Glomb, T., Cedzich, S., Broniecka, U., \& Kuchar, E. (2016). Usage of over-the-counter and herbal products in common cold in Poland: Findings from consumer survey. Advances in Experimental Medicine and Biology, 878(August 2015), $21-27$.

Kaufmann, H. R., Panni, M. F. A. K., \& Orphanidou, Y. (2012). Factors Affecting Consumers ' Green Purchasing Behavior : Amifiteratru Economic, XIV(31), 50-69.

Khalek, A. A. (2014). Young Consumers' Attitude towards Halal Food Outlets and JAKIM's Halal Certification in Malaysia. Procedia - Social and Behavioral Sciences, 121(September 2012), 26-34. https://doi.org/10.1016/j.sbspro.2014.01.1105

Khan, T. M., Hassali, M. a, \& Al-haddad, M. S. M. (2011). Nutraceuticals Use among the Inhabitants of Penang, Malaysia Nutraceuticals Use among the Inhabitants of Penang, Malaysia. International Journal of Collaborative Research on Internet Medicine \& Public Healthournal of Collaborative Research on Internet Medicine \& Public Health, 3(5), 402414.

Kim, H. Y., \& Chung, J. E. (2011). Consumer purchase intention for organic personal care products. Journal of Consumer Marketing, 28(1), 40-47. https://doi.org/10.1108/07363761111101930

Kock, N. (2015). Common method bias in PLS-SEM: A full collinearity assessment approach. International Journal of ECollaboration, 11(4), 1-10. https://doi.org/10.4018/ijec.2015100101

Kumar, P., \& Ghodeswar, B. M. (2015). Factors affecting consumers' green product purchase decisions. Marketing Intelligence and Planning, 33(3), 330-347. https://doi.org/10.1108/MIP-03-2014-0068

Kusumawardhani, A., Batu, K. L., Aqmala, D., \& Andriyansah. (2019). How green should trust, norm and attitude be colored? 
An empirical research in asian market consumers. Quality - Access to Success, 20(168), 118-126.

Lauche, R., Fuller, N. R., Cramer, H., Wardle, J., Sibbritt, D., \& Adams, J. (2018). Complementary Therapies in Medicine Associations between complementary medicine, satisfaction with body weight and shape, and the use of methods to lose or control weight: Results of a national survey of 8009 Australian women. Complementary Therapies in Medicine, 36(November 2017), 100-106. https://doi.org/10.1016/j.ctim.2017.12.008

Lee, D. Y. W., Li, Q. Y., Liu, J., \& Efferth, T. (2020). Traditional Chinese herbal medicine at the forefront battle against COVID-19 : Clinical experience and scientific basis. Phytomedicine, 153337.

Li, L., Long, X., Laubayeva, A., Cai, X., \& Zhu, B. (2020). Behavioral intention of environmentally friendly agricultural food: the role of policy, perceived value, subjective norm. Environmental Science and Pollution Research, 27(15), 1894918961. https://doi.org/10.1007/s11356-020-08261-x

Lim, Y. J., Osman, A., Salahuddin, S. N., Romle, A. R., \& Abdullah, S. (2016). Factors Influencing Online Shopping Behavior: The Mediating Role of Purchase Intention. Procedia Economics and Finance, 35(October 2015), 401-410.

Lin, N. H., Yang, H. W., Su, Y. J., \& Chang, C. W. (2019). Herb induced liver injury after using herbal medicine: A systemic review and case-control study. Medicine, 98(13), e14992. https://doi.org/10.1097/MD.0000000000014992

Lodorfos, G. N., Mulvana, K. L., \& Temperley, J. (2006). Consumer Behaviour: Experience,Price, Trust and Subjective Norm in OTC Pharmaceutical Market. Spec. Ed. Cust. Satisf. - Glob. Perspect., 41-66.

Lutz, F. (1999). Present and Future Regulations For Herbal Medicinal Products In the EU. Pharmaceuticals Policy and Law, $2,17-25$.

Lynch, N., \& Berry, D. (2007). Differences in perceived risks and benefits of herbal, over-the-counter conventional, and prescribed conventional, medicines, and the implications of this for the safe and effective use of herbal products. Complementary Therapies in Medicine, 15(2), 84-91. https://doi.org/10.1016/j.ctim.2006.06.007

Mackenzie, S. B., \& Podsakoff, P. M. (2003). A Critical Review of Construct Indicators and Measurement Model Misspecification in Marketing and Consumer Research. Journal of Consumer Research, 30(2), 199-218.

Magkos, F., Arvaniti, F., \& Zampelas, A. (2006). Organic Food: Buying More Safety or Just Peace of Mind? A Critical Review of the Literature. Critical Reviews in Food Science and Nutrition, 46(1), 23-56.

Mahomoodally, M. F., \& Ramalingum, N. (2015). An investigation into the consumption patterns, attitude, and perception of Mauritians towards common medicinal food plants. Journal of Herbal Medicine, 5(2), 99-112.

Maichum, K., Parichatnon, S., \& Peng, K. C. (2016). Application of the extended theory of planned behavior model to investigate purchase intention of green products among Thai consumers. Sustainability (Switzerland), 8(10), 1-20.

Marimuthu, M. (2019). Young mothers' acceptance of herbal food supplements: Centred on preventive health behaviour for children. Retailing and Consumer Service, 51, 311-319.

Marinac, J. S., Buchinger, C. L., Godfrey, L. a, Wooten, J. M., Sun, C., \& Willsie, S. K. (2005). Knowledge Among Older Adults. Puerto Rico Health Sciences Journal, 24(4), 277-286.

Mazhar, H., Harkin, E. F., Foster, B. C., \& Harris, C. S. (2016). Complementary and Alternative Medicine use in Pediatric Attention-Deficit Hyperactivity Disorder (ADHD): Reviewing the Safety and Efficacy of Herbal Medicines. Current Developmental Disorders Reports, 3(1), 15-24. https://doi.org/10.1007/s40474-016-0074-x

Michaelidou, N, \& Hassan, L. M. (2008). The push and pull towards organic: clarifying the roles of health consciousness, food safety concern and ethical identity. International Journal of Consumer Studies, 32(2), 163-170.

Michaelidou, Nina, \& Hassan, L. (2014). New advances in attitude and behavioural decision-making models. Journal of Marketing Management, 30(5-6), 519-528. https://doi.org/10.1080/0267257X.2014.884368

MIDA. (2020). Herbal Industry: Nutraceutiacal,Health Supplements and Traditional Medicines in Malaysia.

Mihaela-Roxana, I., \& Yoon, C. C. (2010). Analyzing The Effects Of Product Label Massage On Consumers' Attitude and Intention. Journal of Business \& Economic Research, 8(11), 125-136.

Mitha, S., Nagarajan, V., Babar, M. G., Siddiqui, M. J. A., \& Jamshed, S. Q. (2013). Reasons of using complementary and alternative medicines (CAM) among elderly Malaysians of Kuala Lumpur and Selangor states: An exploratory study. Journal of Young Pharmacists, 5(2), 50-53. https://doi.org/10.1016/j.jyp.2013.05.002

Mohammed, A. A. (2020). What motivates consumers to purchase organic food in an emerging market? An empirical study from Saudi Arabia. British Food Journal, 123(5), 1758-1775. https://doi.org/10.1108/BFJ-07-2020-0599

Moshi, F. V., Kibusi, S. M., \& Fabian, F. (2020). Exploring factors influencing pregnant Women's attitudes, perceived subjective norms and perceived behavior control towards male involvement in maternal services utilization: a baseline findings from a community based interventional study from Rukwa, rura. BMC Pregnancy and Childbirth, 20(1), 1-12.

Muhamad, S., Sulaiman, N. F. C., \& Saputra, J. (2018). The role of human capital and innovation capacity on economic growth in ASEAN-3. Jurnal Ekonomi Malaysia, 52(1), 281-294.

Nair, K. V, \& Pillai, P. (2011). A study on purchase pattern of cosmetics among consumers in Kerala. International Marketing Conference on Marketing \& Society, 4(8), 581-595.

Napoli, P. M. (2010). Revisiting "mass communication" and the "work" of the audience in the new media environment. Media, Culture and Society. https://doi.org/10.1177/0163443710361658

Navarro, V. (2019). Liver Injury from Herbal and Dietary Supplements: An Introduction. Clinical Liver Disease, 14(2), 4344. https://doi.org/10.1002/cld.870

Nguyen, L. T. Van, Nayak, R., Watkins, J., \& Nguyen, P. N. D. (2019). Drivers of social media disengagement: a study of young consumers in Vietnam. Young Consumers, 21(2), 155-170. https://doi.org/10.1108/YC-01-2019-0938

Nik Yusof Fuad, N. F., Ching, S. M., Awg Dzulkarnain, D. H., Cheong, A. T., \& Zakaria, Z. A. (2020). Complementary 
alternative medicine use among postpartum mothers in a primary care setting: a cross-sectional study in Malaysia. $B M C$ Complementary Medicine and Therapies, 20(1), 197. https://doi.org/10.1186/s12906-020-02984-7

Nookabkaew, S., Rangkadilok, N., \& Jutamaad, S. (2006). Determination of trace elements in herbal tea products and thier infusions. Journal of Agricultural and Food Chemistry, 54, 6939-6944. https://doi.org/10.1021/jf060571w

NPRA. (2020). National Pharmaceutical Regulatory Agency.

Nur Nadirah, M. S., Ghazali, H., Bakar, A. Z. ., \& Othman, M. (2016). Understanding media literacy in relation to adolescent soft drink consumption behavior. International Food Research Journal, 23(1), 381-388.

Ogiemwonyi, O., \& Harun, A. Bin. (2020). Consumption of Green Product as a Means of Expressing Green Behaviour in an Emerging Economy: With the Case Study of Malaysia. Environment and Urbanization ASIA, 11(2), $297-312$. https://doi.org/10.1177/0975425320938538

Ogiemwonyi, O., Harun, A. Bin, Alam, M. N., Karim, A. M., Tabash, M. I., Hossain, M. I., Aziz, S., Abbasi, B. A., \& Ojuolape, M. A. (2020). Green product as a means of expressing green behaviour: A cross-cultural empirical evidence from Malaysia and Nigeria. Environmental Technology and Innovation, 20, 101055.

Oketch-Rabah, H. A., Roe, A. L., Rider, C. V., Bonkovsky, H. L., Giancaspro, G. I., Navarro, V., Paine, M. F., Betz, J. M., Marles, R. J., Casper, S., Gurley, B., Jordan, S. A., He, K., Kapoor, M. P., Rao, T. P., Sherker, A. H., Fontana, R. J., Rossi, S., Vuppalanchi, R., ... Ko, R. (2020). United States Pharmacopeia (USP) comprehensive review of the hepatotoxicity of green tea extracts. Toxicology Reports, 7(February), 386-402. https://doi.org/10.1016/j.toxrep.2020.02.008

Parle, M., \& Bansap, N. (2005). Herbal Medicines: Are they safe? Natural Product Radiance, 5(1), 6-14.

Perrea, T., Grunert, K. G., \& Krystallis, A. (2015). Consumer value perceptions of food products from emerging Processing technologies: A cross-cultural exploration. Food Quality and Preference, 39, 95-108.

Podsakoff, P.M., MacKenzie, S. B., \& Podsakoff, N. P. (2011). Sources of method bias in social science research and recommendations on how to control it. Annual Review of Psychology, 63(1), 539-569.

Podsakoff, Philip M., MacKenzie, S. B., Lee, J.-Y., \& Podsakoff, N. P. (2003). Common Method Biases in Behavioral Research: A Critical Review of the Literature and Recommended Remedies. Journal of Applied Psychologysychology, 88(5), 879-903. https://doi.org/10.1037/0021-9010.88.5.879

Podsakoff, Philip M., MacKenzie, S. B., \& Podsakoff, N. P. (2012). Sources of Method Bias in Social Science Research and Recommendations on How to Control It. Annual Review of Psychology, 63(1), 539-569.

Policarpo, M. C., \& Aguiar, E. C. (2020). How self-expressive benefits relate to buying a hybrid car as a green product. Journal of Cleaner Production, 252, 119859. https://doi.org/10.1016/j.jclepro.2019.119859

Pujari, N. M., Professor, A., Neelkanth, P., Anupam, S., \& Deepika, G. (2015). Indian Consumer's Buying Behaviour and Perception To Herbal Drugs: A Report. International Journal of Progressive Pharmacy, 1(1), 11-19.

Qian, Q., Chen, W., Cao, Y., Cao, Q., Cui, Y., Li, Y., \& Wu, J. (2019). Targeting Reactive Oxygen Species in Cancer via Chinese Herbal Medicine. Oxidative Medicine and Cellular Longevity, 2019. https://doi.org/10.1155/2019/9240426

QYR Research. (2019). Global OTC Herbal and Traditional Medicines Industry Research Report, Growth Trends and Competitive Analysis 2019-2025.

Rahnama, H. (2016). Effect of Consumers' Attitude on Buying Organic Products in Iran. Journal of Food Products Marketing. https://doi.org/10.1080/10454446.2014.949976

Ramayah, T., Lee, J. W. C., \& Mohamad, O. (2010). Green product purchase intention: Some insights from a developing country. Resources, Conservation and Recycling, 54(12), 1419-1427. https://doi.org/10.1016/j.resconrec.2010.06.007

Ramya, N., \& Ali, D. S. M. (2016). Factors affecting consumer buying behavior. International Journal of Applied Research. https://doi.org/2394-5869

Rana, J., \& Paul, J. (2017). Consumer behavior and purchase intention for organic food: A review and research agenda. Journal of Retailing and Consumer Services, 38(February), 157-165. https://doi.org/10.1016/j.jretconser.2017.06.004

Real, M., Barnhill, M. S., Higley, C., Rosenberg, J., \& Lewis, J. H. (2019). Drug-Induced Liver Injury: Highlights of the Recent Literature. Drug Safety, 42(3), 365-387. https://doi.org/10.1007/s40264-018-0743-2

Reda, M., Taddele, H., Afera, B., Bsrat, A., Abera, E., Hurrissa and Eshetu, Sawant, A. A., Hegde, N. V., Straley, B. A., Donaldson, S. C., Love, B. C., Knabel, S. J., Jayarao, B. M., Marshall, B. M., Levy, S. B., Zdolec, N., Dobranić, V., Butković, I., Koturić, A., ... References, C. (2014). Socioeconomic and demographic profile and functionality of elderly served by the Family Health Strategy in Paranoá, Federal District, Brazil. https://doi.org/10.1590/s180998232013000400007

Report Globe. (2020). Global (Covid-19 Impact)Herbal Sales Market (Sales,Revenue And Competitors Analysis Of Major Market) From 2014-2026.

Research And Markets. (2020). Asia \& ASEAN Herbal Medicines Market.

Rezai, G, Mohamed, Z., Shamsudin, M. N., \& Zahran, M. Z. (2013). Effect of Consumer Demographic Factors on Purchasing Herbal Products Online in Malaysia. International Journal of Social, Management, Economics and Business Engineering, 7(8), 529-535.

Rezai, Golnaz, Shamsudin, M. N., Mohamed, Z., \& Sook Ann, C. (2014). Quality-Labeled Vegetable Consumption in Malaysia: Factors Affecting Attitude and Purchase Intent. Journal of Food Products Marketing, 20(December 2014), 112. https://doi.org/10.1080/10454446.2014.921871

Rezai, Golnaz, Zahran, M. Z. M., Mohamed, Z., \& Sharifuddin, J. (2013). Factors influencing Malaysian consumers online purchase of herbal products. Pertanika Journal of Social Science and Humanities, 21(August), 109-122.

Richards, I., Tesson, S., Porter, D., Phillips, K. A., Rankin, N., Musiello, T., Marven, M., \& Butow, P. (2016). Predicting 
women's intentions for contralateral prophylactic mastectomy: An application of an extended theory of planned behaviour. European Journal of Oncology Nursing, 21, 57-65. https://doi.org/10.1016/j.ejon.2015.12.002

Ringle, C. M. W., Becker, S. \&, \& Jan-Micheal. (2015). SmartPLS3.

Ritchie, M. R. (2007). Use of herbal supplements and nutritional supplements in the UK: what do we know about their pattern of usage? The Proceedings of the Nutrition Society, 66(4), 479-482. https://doi.org/10.1017/S0029665107005794

Rojas-Rivas, E., Espinoza-Ortega, A., Martínez-García, C. G., Moctezuma-Pérez, S., \& Thomé-Ortiz, H. (2018). Exploring the perception of Mexican urban consumers toward functional foods using the Free Word Association technique. Journal of Sensory Studies, 33(5), 1-11. https://doi.org/10.1111/joss.12439

Sabery, M., Adib-Hajbaghery, M., \& Rafiee, S. (2019). Satisfaction with and factors related to medicinal herb consumption in older Iranian adults. European Journal of Integrative Medicine, 25(October 2018), 100-105. https://doi.org/10.1016/j.eujim.2018.12.005

Shafiq, R., Raza, I., \& Zia-ur-Rehman, M. (2011). Analysis of the factors affecting customers' purchase intention: The mediating role of perceived value. African Journal of Business Management, 5(26), 10577-10585. https://doi.org/http://dx.doi.org/10.5897/AJBM10.1088

Shaharudin, M. R., Pani, J. J., Mansor, S. W., Elias, S. J., \& Sadek, D. M. (2010). Purchase Intention of Organic Food in Kedah , Malaysia; A Religious Overview. International Journal of Marketing Studies, 2, 96-103. https://doi.org/10.5539/ijms.v2n1p96

Shaito, A., Thi, D., Thuan, B., Phu, H. T., Hieu, T., Nguyen, D., \& Fan, G. (2020). Herbal Medicine for Cardiovascular Diseases : Effi cacy, Mechanisms, and Safety. 11(April), 1-32. https://doi.org/10.3389/fphar.2020.00422

Sharma, M., \& Trivedi, P. (2016). Various Green Marketing Variables and Their Effects on Consumers' Buying Behaviour for Green Products. Ijltemas, $V(1), 1-8$.

Shi, H., Wang, S., \& Guo, S. (2019). Predicting the impacts of psychological factors and policy factors on individual's PM2.5 reduction behavior: An empirical study in China. Journal of Cleaner Production, 241, 118416. https://doi.org/10.1016/j.jclepro.2019.118416

Shih, C. C., Huang, L. H., Yeh, C. C., Lane, H. L., Hsieh, C. J., Tsai, C. C., Lin, L. W., Chen, T. L., \& Liao, C. C. (2017). The prevalence, characteristics, and factors associated with purchasing Chinese herbal medicine among adults in Taiwan. BMC Complementary and Alternative Medicine, 17(1), 1-7. https://doi.org/10.1186/s12906-017-1679-2

Shmueli, G., Sarstedt, M., Hair, J. F., Cheah, J. H., Ting, H., Vaithilingam, S., \& Ringle, C. M. (2019). Predictive model assessment in PLS-SEM: guidelines for using PLSpredict. European Journal of Marketing, 53(11), 2322-2347. https://doi.org/10.1108/EJM-02-2019-0189

Silva, P. de, \& Sandika, S. (2011). Quality Standard Labeling Information on Meat Packs Demanded by Consumers and Relationships with Purchasing Motives. Jiangsu Nong Ye Xue Bao, 6(2), 85-90. https://doi.org/10.4038/jas.v6i2.3863

Simpson, J. J., Simpson, P. M., \& Cruz-Milán, O. (2016). Attitude towards immigrants and security: Effects on destinationloyal tourists. Tourism Management, 57, 373-386. https://doi.org/10.1016/j.tourman.2016.06.021

Spears, N., \& Singh, S. N. (2004). Measuring attitude toward the brand and purchase intentions. Journal of Current Issues and Research in Advertising, 26(2), 53-66. https://doi.org/10.1080/10641734.2004.10505164

Sreen, N., Purbey, S., \& Sadarangani, P. (2018). Impact of culture, behavior and gender on green purchase intention. Journal of Retailing and Consumer Services, 41(December 2017), 177-189. https://doi.org/10.1016/j.jretconser.2017.12.002

Stern, P. C. (2000). Stern 's Attitude-Behaviour-Context Model. 2000.

Sultan, P., Tarafder, T., Pearson, D., \& Henryks, J. (2020). Intention-behaviour gap and perceived behavioural controlbehaviour gap in theory of planned behaviour: moderating roles of communication, satisfaction and trust in organic food consumption. Food Quality and Preference, 81, 103838. https://doi.org/10.1016/j.foodqual.2019.103838

Sumngern, C., Azeredo, Z., Subgranon, R., Matos, E., \& Kijjoa, A. (2011). The perception of the benefits of herbal medicine consumption among the Thai elderly. Journal of Nutrition, Health and Aging, 15(1), 59-63. https://doi.org/10.1007/s12603-011-0013-9

Sun, Q., He, Y., Wang, Y., \& Ma, F. (2019). Evolutionary Game between Government and Ride-Hailing Platform : Evidence from China. 2019.

Syima, N., Nah, M., Ismail, S., Ramayah, T., Rusafila, Z., Hassan, A., \& Rajeh, J. (2019). Modelling the Use of Grabcar Ridesharing Services. International Journal of Recent Technology and Engineering, 8(2), 316-323. https://doi.org/10.35940/ijrte.B1055.0782S219

Tan, C. N. L., Ramayah, T., \& Popa, S. (2017). KMS self-efficacy, KMS quality, expected reward and subjective norm: investigating knowledge sharing attitude of Malaysia's Halal industry. European J. of International Management, 11(4), 407. https://doi.org/10.1504/EJIM.2017.085581

Tan, T. Y. C., Lee, J. C., Mohd Yusof, N. A., Teh, B. P., \& Syed Mohamed, A. F. (2020). Malaysian herbal monograph development and challenges. Journal of Herbal Medicine, 23, 100380. https://doi.org/10.1016/j.hermed.2020.100380

Tangkiatkumjai, M., Boardman, H., Praditpornsilpa, K., \& Walker, D. M. (2013). Prevalence of herbal and dietary supplement usage in Thai outpatients with chronic kidney disease: a cross-sectional survey. BMC Complementary and Alternative Medicine, 13(1), 153. https://doi.org/10.1186/1472-6882-13-153

Taufique, K. M. R., \& Vaithianathan, S. (2018). A fresh look at understanding Green consumer behavior among young urban Indian consumers through the lens of Theory of Planned Behavior. Journal of Cleaner Production, 183, 46-55. https://doi.org/10.1016/j.jclepro.2018.02.097

Thanisorn, R., Byaporn, N., \& Chanchai, B. (2012). Thai Consumers' Perception on Herbal Cosmetic Products: A 
Comparative Study of Thai and Imported Products. Information Management and Business Review, 4(1), 35-40.

Thongruang, C. (2008). Consumer Purchasing Behavior for Herbal Medicine in Drugstore in Bangkok. Naresuan University Journal, 16(3), 195-202.

Tleis, M., Callieris, R., \& Roma, R. (2017). Segmenting the organic food market in Lebanon: an application of k-means cluster analysis. British Food Journal, 119(7), 1423-1441. https://doi.org/10.1108/BFJ-08-2016-0354

Vadakepat, V. M. (2013). Multi-culture consumer behaviour in the Abu Dhabi markets. Education, Business and Society: Contemporary Middle Eastern Issues, 6(1), 42-54. https://doi.org/10.1108/17537981311314718

Valeckova, J. (2012). The Analysis of the Influence of Residence in the Purchase of Pharmaceutical Products. Journal of Competitiveness, 4(1), 56-68. https://doi.org/10.7441/joc.2012.01.05

Vani, G., Ganesh Babu, M., \& Panchanatham, N. (2010). Toothpaste products-Analysis of consumer behavior in Bangalore city. Journal of Economics and Behavioral Studies, 1(1), 27-39.

Vries, H. de, Kuhlman, P., \& Dijkstra, M. (1988). Self efficacy; The third factor besides attitude and subjective norm as a pradictor of behavioral intentions. Health Education Research, 3(3), 273-280.

Wahab, M. S. A., Sakthong, P., \& Winit-Watjana, W. (2019). Qualitative exploration of pharmacist care for herbal and dietary supplement users in Thai community pharmacies. Journal of Pharmaceutical Health Services Research, 10(1), 57-66. https://doi.org/10.1111/jphs.12238

Warner, H. W., \& Forward, S. (2016). The effectiveness of road safety interventions using three different messages: Emotional, factual or a combination of both messages. Transportation Research Part F: Traffic Psychology and Behaviour, 36, 25-34. https://doi.org/10.1016/j.trf.2015.11.002

Wegener, T. (2017). Patterns and Trends in the Use of Herbal Products, Herbal Medicine and Herbal Medicinal Products. International Journal of Complementary \& Alternative Medicine, 9(6). https://doi.org/10.15406/ijcam.2017.09.00317

Welz, A. N., Emberger-Klein, A., \& Menrad, K. (2018). Why people use herbal medicine: Insights from a focus-group study in Germany. BMC Complementary and Alternative Medicine, 18(1), 1-9. https://doi.org/10.1186/s12906-018-2160-6

Wilcock, A., Pun, M., Khanona, J., \& Aung, M. (2004). Consumer attitudes, knowledge and behaviour: A review of food safety issues. Trends in Food Science and Technology, 15(2), 56-66. https://doi.org/10.1016/j.tifs.2003.08.004

Wilhoite, A. P., Knell, J. K., \& González-Espada, W. (2014). Use Of Herbal Supplements among College Students in Eastern Kentucky : Impact Factors. Journal of the Kentucky Academy, 75(1), 53-68.

Woolf, A. D. (2003). Herbal remedies and children: do they work? Are they harmful? Pediatrics, 112(1 Pt 2), $240-246$. https://doi.org/10.1542/peds.112.1.S1.240

Xu, X., Maki, A., Chen, C. fei, Dong, B., \& Day, J. K. (2017). Investigating willingness to save energy and communication about energy use in the American workplace with the attitude-behavior-context model. Energy Research and Social Science, 32, 13-22. https://doi.org/10.1016/j.erss.2017.02.011

Yeh, M. H., Wu, H. C., Lin, N. W., Hsieh, J. J., Yeh, J. W., Chiu, H. P., Wu, M. C., Tsai, T. Y., Yeh, C. C., \& Li, T. M. (2020). Long-term use of combined conventional medicine and Chinese herbal medicine decreases the mortality risk of patients with lung cancer. Complementary Therapies in Medicine, 52, 102427. https://doi.org/10.1016/j.ctim.2020.102427

Zahran, M. Z. M., Rezai, G., \& Mohamed, Z. (2012). Predicting Consumer Intentions To Shop Herbal Products Online: an Empirical Investigation. 2nd INTERNATIONAL CONFERENCE ON MANAGEMENT (2nd ICM 2012) PROCEEDING, June, 984-995.

Zhang, Y., Wu, S., \& Rasheed, M. I. (2020). Conscientiousness and smartphone recycling intention: The moderating effect of risk perception. Waste Management, 101, 116-125. https://doi.org/10.1016/j.wasman.2019.09.040

Zhou, X., Li, C., Chang, D., \& Bensoussan, A. (2019). Current Status and Major Challenges to the Safety and Efficacy Presented by Chinese Herbal Medicine. https://doi.org/10.3390/medicines6010014

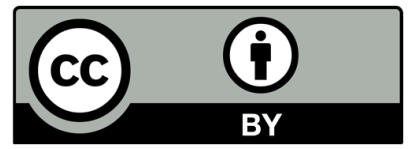

(C) 2021 by the authors; licensee Growing Science, Canada. This is an open access article distributed under the terms and conditions of the Creative Commons Attribution (CC-BY) license (http://creativecommons.org/licenses/by/4.0/). 